\title{
Revisiting Restoration Theatre through Transnational Interactions
}

\author{
Simona Hájková
}

English Theatre Culture 1660-1737. The Department of Theatre Studies and the Department of English and American Studies. Faculty of Arts. Masaryk University Brno. 12-21 October 2020. Online.

Since 2019, the Department of Theatre Studies and the Department of English and American Studies in Brno have become the home of a research team which investigates English theatre culture of the Restoration and early eighteenth-century periods (see also KRAJNÍK et al. 2019a and KRAJNÍK et al. 2019b). Apart from bringing new translations of two dozen plays from the period and up-to-date scholarship on it to Czech readers for the first time, one of the objectives of the project (financed by the Czech Science foundation, GAČR) is to foster a broader international community of researchers interested in "late" early modern theatre, literature and culture, who would share their ideas and collaborate even after the official end of the project.

One of the important steps in achieving this goal was the first in a series of international symposia entitled English Theatre Culture 1660-1737, which took place between $12^{\text {th }}$ and $21^{\text {st }}$ October 2020, and was organised by the research team of the aforementioned project. Due to the pandemic situation in the Czech Republic and the rest of the world, which did not allow for the usual, face-to-face format of the event, the conference was held online. As the saying goes, however, every cloud has a silver lining, and in this case, the online form enabled a wide variety of speakers from three continents to participate in four intensive days of lectures and seminars.

The subtitle of the symposium was "Forms, Genres and Conventions", its aim being to address Restoration theatre as a multi-genre phenomenon, a crossroads of sorts where multiple forms and traditions met to create a unique theatre culture, richer and more diverse in inspirations than has traditionally been acknowledged by literary historians.

The first day of the event, focused on the issues of "Music and Musical Genres of English Restoration Theatre", began with a plenary lecture by Amanda Eubanks Winkler (Syracuse University, USA) and aimed at the relationship between the past and present when referring to plays and their performances. Professor Eubanks Winkler took as her point of departure the concept of syncopated time and used it as a lens to study Restoration musical adaptations of Shakespeare's plays. In her talk, she focused on the expectations of modern audiences and their relation to original practices when staging various versions of The Tempest nowadays. As a musicologist and drama specialist, Prof. Eubanks Winkler took part in a stage project held at the Sam Wanamaker Playhouse, 
Shakespeare's Globe, London, in 2017, which explored the possibilities of presentday stagings of Restoration adaptations probing whether it is more acceptable for a modern audience to see a performance that is historically accurate or whether to adjust the play to our modern age, with the ability to utilise its technology and variable theatrical space. This was put into practice when rehearsing the Dryden-DavenantShadwell operatic adaptation of Shakespeare's The Tempest (1674) with the music by Matthew Locke (which came from an early 1700 s adaptation, as the score of the 1670s has not survived). Among the issues that Eubanks Winkler and her team had to face was the fact that little of the material describing the musical pieces and their staging survives today. After creating as historically accurate a restaging of the original performance as possible, Eubanks Winkler summarised the findings of the practical exploration as suggesting, judging by the audience responses, that historical plays should be adjusted to fit modern audiences and their expectations. In this way, the temporal disruption, when past and present mingle together, is needed when performing a play that was written and staged for an audience of a different theatre culture. (For more about Professor Eubanks Winkler's projects, see the interview with her in this volume.)

The first part of the seminar that followed opened with a paper by Dóra Janczer Csikós (Eötvös Loránd University, Hungary) on the reception of Italian opera in England, in which the presenter focused on the rather reluctant manner in which Italian opera was originally accepted by English audiences and how the refusal of the foreign genre influenced the visual arts of the period. Afterwards, the floor was taken by Andrew Walkling (Binghamton University, USA), whose topic was the genre of the "dramatick opera" and its origins. Walkling introduced the concept of the so-called diegetic supernaturalism that helped with the establishment of the operatic genre in England by naturally incorporating song passages into the mythological worlds of the dramatic pieces. He also observed the use of diverse stage effects and how these contributed to the establishment of the English dramatick opera as a distinct theatrical form.

The second half of the seminar started with JoAnn Taricani's (University of Washington, USA) talk on the political dimension of the nationally charged myth of the Dragon of Wantley. A special focus was given to the several versions and musical adaptations of the myth, as it changed throughout the history in relationship to the political background of the late seventeenth century in the course of which it was adapted. Political criticism included in each of the versions from 1685 and 1737 was also commented on. Stacey Jocoy (Texas Tech University, USA) concluded the day with a paper that analysed the medley of songs which Captain Macheath sings before his execution in Gay's Beggar's Opera (1728) and its multi-layered meaning. Jocoy pointed out that the scene was, among other things, supposed to mirror the tendency of the early $18^{\text {th }}$ century to abandon the stock character of Restoration cavalier, which Captain Macheath challenged. ${ }^{1}$

The second day of the conference, entitled "Understudied Forms and Genres of the Restoration and Early $18^{\text {th }}$-Century

1 An elaborated version of Stacey Jocoy's paper is published in this volume. 
English Drama", opened with a plenary lecture by Claudine van Hensbergen (Northumbria University, UK) on the importance of visual monuments in Restoration theatre performances during 16691677. Van Hensbergen capitalised on the importance of artwork in the theatre, such as sculptures, engravings and paintings, which complemented the visual settings of the scene. She analysed at length the engravings included in the 1673 edition of Elkanah Settle's The Empress of Morocco and the sculptor Grinling Gibbons and his woodwork, which remains a great architectural achievement of the period. Van Hensbergen concluded that the overall experience of the theatregoers did not come solely from the play's text and stage scenery, but that the variety of other decorative artwork in theatre interiors actively contributed to the meaning of the performance and should be taken into consideration in order to understand the summative effect of Restoration staging.

The seminar session that followed opened with Stephen Watkins (University of Derby, UK) and his talk on the typical and widely studied genre of the Restoration heroic play. In his paper, Watkins addressed the origins and the development of the genre, proposing a new methodology commonly used in film theory. Rather than following the traditional definition established by the aesthetic assessment of literary critics, Watkins examined the early heroic tragedies from the perspective of a producer, in this case theatre managers William Davenant and Thomas Killigrew, who worked with a certain generic blueprint in order to increase the chances of commercial success. Taking the producer's decisions into account enabled Watkins to demonstrate that the actual prototype of a heroic play was not Davenant's conventionally quoted The Siege of Rhodes (1656) but Howard and Dryden's The Indian Queen (1664). His presentation also reassessed the competition between the King's and the Duke's theatre companies, crediting the latter with being the driving force behind the development of the heroic play, which has far-reaching implications for the theatre industry of the time. A paper by Misty G. Anderson (University of Tennessee, USA) followed on the tradition of early eighteenth-century harlequinades and their (what she referred to as) supernaturalism. Anderson put her main focus on the way in which the Harlequin character got entangled with the Faustian myth, which ultimately affected the trajectory of the individual plotlines, emphasising the punishment of the trickster for his behaviour. Anderson interpreted the Faustian ambition and Harlequin's punishment as an allegory of early capitalism and a warning against the excesses of middle-class indulgence in the pleasures of the growing global marketplace. The presentation also made an interesting comment on the issues of the blackness of Harlequin's mask, which demonized black people in direct connection to the flourishing slave trade.

In the second part of the seminar, Lucie Skeaping and Tamsin Lewis presented short stage comedy genres of the seventeenth century, namely the jig and droll, Singing Simpkin and The Humour of John Swabber, respectively, with the recordings of actual performances of these two plays as they had reconstructed and produced them. Both Skeaping and Lewis introduced the characteristic features of these short dramas, such as dance, comedy and stock characters well-known to the audience (faithless wives, cuckolded husbands, 
foolish constables, etc.), as well as how they went about the uneasy task of bringing these forms back to life for modern audiences. Although we nowadays tend to associate the jig and the droll chiefly with the pre-Restoration era, they both enjoyed popularity even after 1660 and were not restricted only to England, but also circulated across the European continent.

The third day of symposium, themed "Adaptations, Appropriations and Afterlives on Restoration Stages", started with Teresa Grant's (University of Warwick, UK) plenary lecture on James Shirley, the revisions of his plays by Aphra Behn, and the issue of crossdressing in regard to the female parts, originally performed by male actors, but later by actresses, which significantly shifted the gender and sexual dynamics of the pieces. The main focus of the lecture was given to Shirley's The Lady of Pleasure (1635) and the way in which certain motifs and situations of the play were deployed by Behn in her play The Lucky Chance (1686).

The seminar papers that followed all addressed the issue of Restoration adaptations from various perspectives. If there was a unifying theme of the presentations, it was the adaptations' ability to absorb new, often subversive ideas. Angelina Del Balzo (Bilkent University, Turkey) demonstrated how, although considered derivative and of secondary importance by some, adaptations could in fact contribute to the development of theatre genres, especially Restoration tragedy in relation to female emotion. Nathan Richards-Velinou (McGill University, Canada) and Lisanna Calvi (University of Verona, Italy) addressed the issues of how gender and sexuality were re-negotiated on the Restoration stage under the guise of Shakespeare. Eva
Bilská (Charles University, Czech Republic) showed how mid and late seventeenthcentury philosophical and political thinking influenced the Restoration rewriting (and staging) of Shakespeare's Macbeth (1674).

In the second half of the day, Lauren Liebe (Texas A\&M University, USA) argued that Robert Howard's play The Great Favourite, or the Duke of Lerma (1668) was significantly shaped by contemporary court politics. Angelica Vedelago (University of Verona, Italy) discussed the ways in which Sophocles and Seneca in Dryden and Lee's Oedipus (1678) addressed the status and absorption of classical sources in the Restoration period. The seminar concluded with Andrew Walkling's paper on Edmund Waller's re-scripting of the final act of Francis Beaumont and Fletcher's The Maid's Tragedy (1610) and how it reflects Restoration attitudes to monarchy, loyalty and honour.

The last day of the conference, dedicated to "Translation of Drama with a Special View to English Restoration Theatre", opened with Jorge Braga Riera's (Complutense University of Madrid, Spain) plenary lecture on early modern Spanish drama and its translation and staging in Restoration England. In his talk, Braga Riera addressed both the historical and cultural contexts in which Spanish plays were adapted for the English stage, as well as the methods which Restoration translators adopted. Several of these were addressed, such as the importance of deciding between the domesticating and foreignising method - something that remains an issue even for modern translators. Braga Riera also presented the taxonomy of translations by Dryden, pointing out that the Restoration dramatist (and translator 
of drama specifically) openly justified reduction and suppression while translating, and called Dryden rather an imitator for rejecting some parts of the original texts and adding some of his own. In conclusion, Braga Riera claimed that the English translators, with their domesticating method and the use of omission and alteration, tended to push the Spanish authors of the originals to the background.

Afterwards, the first part of the seminar opened with Alba Graziano (University of Tuscia, Italy) and her talk on translation of Restoration comedies into Italian. Graziano focused on the complexities in the translation of Aphra Behn's Sir Patient Fancy (1678) when it comes to the use of the you and thou pronouns. Graziano commented on the differences between English and Italian and their registers, stressing the importance of the context when referring to the use of formal plural and informal singular voi/tu between the characters, as well as the different impacts which the performances in English and Italian had on the audience due to the different use of formal and informal addressing. Mario Valori (Le belle lettere, Italy) discussed the first Italian translation of Thomas Otway's Venice Preserv'd (1680) by Michele Leoni (Venezia Salvata, Florence, 1817). Valori focused on the lexicon and references when regarding the female sphere. Massimiliano Morini (University of Urbino, Italy) presented on the issue of intermediate translation on the case study of Elkanah Settle's version of Giovanni Battista Guarini's Il pastor fido (1589). Settle's stage version, printed in 1677, derived from Richard Fanshawe's 1647 translation, utilising it as an intermediate source.
The second part of the last seminar opened with a paper on Polish translations of Restoration drama, delivered by Anna Cetera-Włodarczyk and Przemysław Pożar (University of Warsaw, Poland). The presenters focused on the reception of Restoration drama in Poland and the contribution of Grzegorz Sinko (1923-2000) to the study of Restoration theatre in Poland, as well as the complicated political situation of the Communist era in which Sinko worked.

While the online format originally seemed to be a disadvantage for the symposium at the beginning, both the presentations and the discussions that followed showed that neither geographical distances nor time differences posed a major obstacle for the event. Apart from the speakers themselves, who mostly attended all of the four seminars and, in the course of the symposium, formed a lively international community, the event was supported by several dozen non-presenting attendees. All the lectures and seminars presented thought-provoking viewpoints of Restoration theatre, addressing both widely and less-widely studied aspects of the performance culture of the period. The present issue of Theatralia offers its readers a selection of essays based on the symposium's presentations (namely by Claudine van Hensbergen, Teresa Grant, Lisanna Calvi, Jorge Braga Riera, Alba Graziano, Massimiliano Morini, and Anna Cetera-Włodarczyk and Przemysław Pożar). Another event of the series of online symposia on Restoration theatre is planned for April 2021, under the title English Theatre Culture 1660-1737: Theatre, Society and Politics. 


\section{Bibliography}

KRAJNÍK, Filip, Anna MIKYŠKOVÁ, Klára ŠKROBÁNKOVÁ, Pavel DRÁBEK and David DROZD. 2019a. English Restoration Theatre in Czech: An Ongoing Research Project Conducted at The Department of English and American Studies and The Department of
Theatre Studies in Brno. THEPES 8 (2019): 1: 123-127.

KRAJNÍK, Filip, Pavel DRÁBEK, David DROZD, Anna MIKYŠKOVÁ and Klára ŠKROBÁNKOVÁ. 2019b. Prolegomena k projektu Anglická divadelni kultura 16601737. Theatralia 22 (2019): 2: 270-273. 